\title{
Development of Contextual-Based Teaching Materials in The Course of Magnetic Electricity
}

\author{
Yaspin Yolanda \\ Physics Education Study Program STKIP PGRI Lubuklinggau \\ Jalan Mayor Toha Taba Pingin, Lubuklinggau City, 31628, Indonesia \\ *Correspondence: yaspinyolanda@ymail.com
}

\begin{tabular}{ll}
\hline Key word: & Abstract \\
Electric Magnet & The purpose of this study is (1). To find out the characteristics of magnetic electric \\
Contextual & teaching materials that fit the needs of STKIP PGRI Lubuklinggau City. (2). To find \\
Teaching materials & out the feasibility of teaching materials. The research and development model used by \\
& the Borg and Gall model, because it is very suitable for developing and validating \\
& educational products. The study was conducted at Physics Student STKIP PGRI \\
& Lubuklinggau who took the Electric Magnet course. Teaching Materials are validated \\
& by experts namely material, language, and graphic design experts. Teaching Materials \\
& are also measured practicality levels with one-to-one trials (Revision-1), small group \\
& trials (Revision-2), and Final tests (Revision-3). Based on the results of the study show \\
& (1) Magnetic electric teaching materials that fit students' needs are contextual based \\
& magnetic electric teaching materials and (2) Based on evaluations following the \\
& suggestions and responses from experts. shows the quality of contextual-based physics \\
& teaching materials with the overall percentage of these components is very feasible. So \\
that magnetic teaching materials are valid and practical.
\end{tabular}

To cite this article:

Yolanda, Y. (2020). Development of Contextual-Based Teaching Materials in The Course of Magnetic Electricity. Thabiea: Journal of Natural Science Teaching, 3(1), 59-69.

\section{Introduction}

Magnetic electricity basically aims to develop students in recognizing natural phenomena, understanding the phenomena and processes of natural events that occur scientifically with the scientific method approach. This is based on the purpose of learning science, which is observing, understanding, and utilizing natural phenomena involving matter (material) and energy, Serway (2009). This is what characterizes the subject of magnetic electricity, Thiagarajan (1974).

The STKIP PGRI Lubuklinggau physics education study program is an education unit that organizes physics teacher preparation programs. The KKNI-based curriculum in physics education study programs always includes electromagnetic subjects as Field Study Expertise (MKKBS). Research results in various countries show that the majority of students have difficulty understanding the concept of electricity-magnetism (Demirci \& Cirkinoglu, 2004; Engelhardt \& Beichner, 2004; Singh, 2006; Planinic, 2006). Some research results in various countries about the difficulties of students in electric-magnet concepts are shown in Table 1. 
Table 1. Research Results of several countries on learning difficulties and student understanding of the subject of magnetic electricity

\begin{tabular}{lll}
\hline $\begin{array}{l}\text { The researcher, year and } \\
\text { source }\end{array}$ & \multicolumn{1}{c}{ The Place } & \multicolumn{1}{c}{ Research Result } \\
\hline $\begin{array}{l}\text { Demirci\&Cirkinoglu, } \\
\text { (2004), Journal of Turkish } \\
\text { Science Education. 1 (2) }\end{array}$ & Turkey & $\begin{array}{l}\text { From the analysis of student responses, it } \\
\text { was found that most students experienced } \\
\text { difficulties in electricity and magnetism. }\end{array}$ \\
\hline $\begin{array}{l}\text { Engelhardt\&Beichner, } \\
\text { (2004), American Journal }\end{array}$ & $\begin{array}{l}\text { Nort California, } \\
\text { America }\end{array}$ & $\begin{array}{l}\text { It was found that many students } \\
\text { experienced magnetic misconceptions } \\
\text { after attending lectures. }\end{array}$ \\
\hline $\begin{array}{l}\text { Singh, (2006), American } \\
\text { Journal of Physics. 74(10) }\end{array}$ & Pittsburgh, & $\begin{array}{l}\text { Many elementary students have } \\
\text { difficulties in the concept of electricity } \\
\text { and magnetism. }\end{array}$ \\
\hline $\begin{array}{l}\text { Planinic, (2006), American } \\
\text { Journal of Physics. 74(12) }\end{array}$ & Zagreb, Croatia & $\begin{array}{l}\text { Of the three groups of students, it } \\
\text { seems that they have difficulties with } \\
\text { the same concept. It was found that } \\
\text { students experienced difficulties in } \\
\text { electromagnetic induction, the } \\
\text { application of Newton's laws in the } \\
\text { context of electricity and magnetism, } \\
\text { and potential and energy. }\end{array}$ \\
& &
\end{tabular}

Suseno (2010)

This research was taken based on observations and interviews with lecturers who taught magnetic electricity courses at STKIP PGRI Lubuklinggau showed that many students who received unsatisfactory grades, namely $\mathrm{C}$ and $\mathrm{D}$. Students still find it difficult to apply or associate between material in daily life. Nugraheni (2017) and Nasir (2017) described the absence of magnetic electric teaching materials makes it easy for students to like these subjects because learning this course is very boring and not contextual. Murtiani (2012) stated that a lecturer must be able to design teaching materials following the analysis of student needs and must be able to answer existing problems. Trianto (2013) believes that a lecturer must be able to make contextual, practical, and effective learning-based learning materials aimed at improving student learning outcomes, attracting students' interest in reading. Nasution (2012) argued that teaching materials can measure knowledge and train student skills. Yolanda (2018) stated that contextual learning is learning that can build meaningfulness (constructivism), discovery-based learning, joint learning (learning community), context-based learning (modeling), authentic assessment and able to measure the level of student ability (authentic assessment), Providing opportunities for students to ask questions (ask questions), and guide students in reviewing material that has been taught (reflection).

Matsun (2018) and Suseno (2010) said magnetic electricity is a very contextual material, interesting and useful, and more students experience and discover electricity as a basic need for lighting according to Serway (2009). Turning on electronic devices that can help human work. The specifications of this study will develop magnetic electric teaching materials that can a) facilitate lecturers in delivering the material so the teaching and learning process gets better; b) facilitate students to learn independently by having contextual-based teaching materials; c) measuring the ability of students in terms of knowledge that is shown by improving learning outcomes, d) teaching materials can be implemented and become 
teaching materials for lectures and; e) overcome the difficulties of learning physics and misconceptions contextually.

\section{Method}

This research was carried out for one year in 2019. The research subjects were 32 physics education students who took the Electric Magnet course in semester 3. The observer involved final semester students. Content validator for Electric and Magnet, a Graphic Design Validator of teaching contents. Furthermore, the symbol and language validator. Utomo (2015) described the model research used is research and development according to Borg and Gall because it is very suitable for developing and validating educational products. Tomlimson (2011), Yasa (2012), and Trianto (2013) described the stages and research methods of the ten steps are shown in Table 2.

Table 2. Research Stages and Methods

\begin{tabular}{|c|c|c|}
\hline No & Stages & Methods \\
\hline 1 & $\begin{array}{l}\text { Research and } \\
\text { Information Collection }\end{array}$ & $\begin{array}{l}\text { a. Observation } \\
\text { b. Observing the atmosphere of learning physics } \\
\text { c. Register all the potential and learning problems } \\
\text { d. Study documentation of student learning outcomes so far. } \\
\text { Questions on the midterm test, final test, assignments, and } \\
\text { RPKPS of the previous year. } \\
\text { e. Analysis of the needs of lecturers and students through } \\
\text { questionnaires and interviews } \\
\text { f. Literatures Review } \\
\text { g. Curriculum analysis based on Competency Standards, Core } \\
\text { Competencies, and Curriculum. }\end{array}$ \\
\hline 2 & Planning & $\begin{array}{l}\text { Compiling contextual electricity-based magnetic teaching } \\
\text { materials. }\end{array}$ \\
\hline 3 & $\begin{array}{l}\text { Initial Product } \\
\text { Development }\end{array}$ & Development of prototype teaching material products. \\
\hline 4 & $\begin{array}{l}\text { Limited trials (one on } \\
\text { one): }\end{array}$ & $\begin{array}{l}\text { a. Expert judgment (validity test) } \\
\text { b. content and context test of the material with a colleague } \\
\text { c. Readability test (suitability test) }\end{array}$ \\
\hline 5 & $1^{\text {st }}$ Product Revision & Test appearance, graphic design of teaching materials. \\
\hline 6 & $\begin{array}{l}\text { Field test (extensive } \\
\text { trials): }\end{array}$ & $\begin{array}{l}\text { a. Expert judgment (validation test) } \\
\text { b. Test content and test the context of the material with a } \\
\text { colleague }\end{array}$ \\
\hline 7 & $2^{\text {nd }}$ Product revision & $\begin{array}{l}\text { a. Readability test (suitability test) } \\
\text { b. Test the appearance and graphic media of teaching materials. }\end{array}$ \\
\hline 8 & Operational field test & $\begin{array}{l}\text { Effectiveness of the use of teaching materials in the third } \\
\text { semester of the Lubuklinggau Physics Education Study Program }\end{array}$ \\
\hline 9 & $\begin{array}{l}\text { Revision of the final } \\
\text { product }\end{array}$ & $\begin{array}{l}\text { The final model of contextual based Electric magnet teaching } \\
\text { materials }\end{array}$ \\
\hline 10 & $\begin{array}{l}\text { Disseminated and } \\
\text { implemented in learning }\end{array}$ & $\begin{array}{l}\text { Socialized in focus group discussions and implemented for } \\
\text { physics lecturers in learning Electric magnetism }\end{array}$ \\
\hline
\end{tabular}

Gall (2010) dan Gay L.R (2009)

Sujanem, R., (2012) and Riadi (2014) argued that data collection techniques in this research and development are carried out with the following techniques are observation, interview, documentation study of Science Process Skills diagnosis test, questionnaire, and 
learning achievement test. In table 3 , this data analysis was carried out at the preliminary stage when developing instructional materials, data analysis at the validation, evaluation, and revision of teaching materials, as well as at the implementation stage of teaching contents.

Table 3. Data Instruments and Analysis

\begin{tabular}{|c|c|c|}
\hline Data Type & Instrument & Data analysis \\
\hline $\begin{array}{l}\text { 1. Student needs } \\
\text { 2. Learning resources } \\
\text { that are being used }\end{array}$ & $\begin{array}{l}\text { a. Initial observation } \\
\text { b. Questionnaire } \\
\text { c. Early diagnosis test forScience Process Skills } \\
\text { d. Interview } \\
\text { e. Analysis of learning resources, analysis of } \\
\text { requirements for Competency Standards, Core } \\
\text { Competencies, and Curriculum. }\end{array}$ & $\begin{array}{l}\text { Percentage } \\
\text { and Descriptive }\end{array}$ \\
\hline Main products & $\begin{array}{l}\text { Format of validation assessment (validation results) } \\
\text { of } 1^{\text {st }} \text { revision and } 2^{\text {nd }} \text { revision }\end{array}$ & $\begin{array}{l}\text { Percentage } \\
\text { and Descriptive }\end{array}$ \\
\hline $\begin{array}{l}\text { Teaching material } \\
\text { products }\end{array}$ & $\begin{array}{l}\text { a. Pretest-postest based on statistical tests to see } \\
\text { improved learning outcomes } \\
\text { b. Learning Activities } \\
\text { c. Implementation of contextual learning } \\
\text { d. Student responses to teaching materials }\end{array}$ & $\begin{array}{l}\text { Percentage } \\
\text { and Descriptive }\end{array}$ \\
\hline
\end{tabular}

Emzir (2013) and Sugiyono (2008)

\section{Results and Discussion}

Based on the needs analysis in the first stage which is identifying the gaps of past and present conditions based on observations researchers get information through observations and direct plunging of spaciousness in STKIP PGRI Lubuklinggau shows that students still experience a lot of magnetic electric misconceptions, errors in unit conversions, difficulties in algebraic operations and eventually magnetism became a scary subject. The ability of instructors must be able to provide contextual perception in real life in understanding the theory of electric magnetism. When delivering an apperception, Tomlimson (2011) stated that the instructor lacked linking theory with real life and the absence of contextual physics-based teaching materials on magnetic electric material.

In the past, students still found it difficult to apply or associate material in daily life. Electric magnetic materials are still less attention. There are no teaching materials based on contextual physics. Now, when the existence of contextual-based physics teaching materials has implemented seven important components in contextual teaching and learning namely constructivism, modeling, inquiry, questions, learning communities, and real authentic assessment. With this contextual physics-based teaching material, students can apply or associate theory with real life and make it easier for students to understand a concept constructively, Fayakun (2015) and Sujanem (2012).

Contextual learning is learning that connects the material learned with the real life of daily students, whether in the family, school, community or citizens, to find meaning from the material for their lives and has seven components of contextual learning that help lecturers in teaching and learning activities because each component is very helpful in the teaching and learning process (Mukayatun, et al., 2013).Murtiani (2012) states that the Directorate General of Primary and Secondary Education has described seven main components of contextual 
learning, namely: (1) Constructivism (constructivism) is the process or compile new knowledge in students' cognitive structures based on personal experiences and phases carried out on conveying perceptions to students before doing the learning process. (2) theinquiry is a learning process based on search and discovery through systematic thinking. Knowledge and skills gained by students are expected not to be the result of remembering a series of facts, but rather the results of the discovery. (3) Asking (asking) is studying the nature of asking and answering, asking questions can be seen as a reflection of each individual's curiosity about something new. (4) Community Learning is cooperation or students learning together to discuss a problem by applying group learning. (5) Modeling is learning by showing various examples that students can imitate. In learning certain skills or knowledge some models can be replicated. (6) Reflection is the process of completing knowledge and experience carried out by reshaping learning events that have been processed. (7) Authentic assessment is a process carried out by lecturers to gather information about the development of learning undertaken by students.

The first R \& D stages according to Emzir (2011) and Law (1991) are writing specific instructional objectives by developing them from basic competencies which are general instructional goals (GIP). Specific Instructional Purpose (SIP) according to Trianto (2013) and Draganidis (2006) that formulates it using the ABCD format (Audiences, Behaviors, Conditions, and Degrees), namely Audience is the intended target, behaviors is an ability that must be possessed by students after participating in learning, the condition shows the initial ability in the assessment process. Furthermore, Itamar (2001) and Kauffman(2009) described the degree shows the level of research subjects. After we have completed the ABCD stage, we make magnetic electric SIPs that are suitable for the learning objectives are shown in Table 4.

Table 4. GIP and SIP Learning

\section{General Instructional Purpose (GIP)}

General instructional objectives in the university physics book, Serway (2009) mentions magnetic electricity consisting of the understanding of magnetic electricity, Orsteed's law, Ohm's, Kirchoff's Law, Faraday's Law, Electromagnetic Induction, Magnetic forces, series circuits, parallel circuits and combined circuits, Wheatstone bridges. The instructional objectives will be applied in contextual physics-based teaching materials on magnetic electric material.

\section{Specific Instructional Purpose (SIP)}

1. After using contextual physics-based teaching materials, students are expected to be able to analyze physics problems using Ohm's Law and Kirchoff's Law 1 which are linked between theory and real-life and know the relationship of physics by looking at strong currents flowing in closed circuits.

2. After using contextual physics-based teaching materials, students are expected to be able to analyze physics problems using Faraday's law and Orsted's laws which are linked between theory and real-life and know the relationship of physics by looking for the magnitude of strong currents flowing in closed circuits.

3. Students can distinguish the arrangement of obstacles arranged in series or parallel with the guided discovery to find the amount of strong current, the amount of voltage flowing in each obstacle.

4. Students can analyze the problem of obstacles arranged in a combined series-parallel to find the magnitude of the current strength, the amount of voltage that flows to each obstacle.

Johnson (2009) and Marreli (2005) stated that at the stage of developing teaching materials on magnetic electric material that was developed by applying seven components, 
became the hallmark of the Contextual Teaching and Learning model in which the seven components would be displayed in these teaching materials based on physical material sources of magnetic electric material. Chaedar (2009), contextual physics-based teaching material on magnetized electric material that was developed contains material, examples of questions, and practice questions along with the overall answer key of a problem contained in the teaching material. The contextual characteristics of electric magnetic teaching materials are shown in Table 5.

Table 5. Contextual Characteristics of Electric Magnetic Teaching Materials

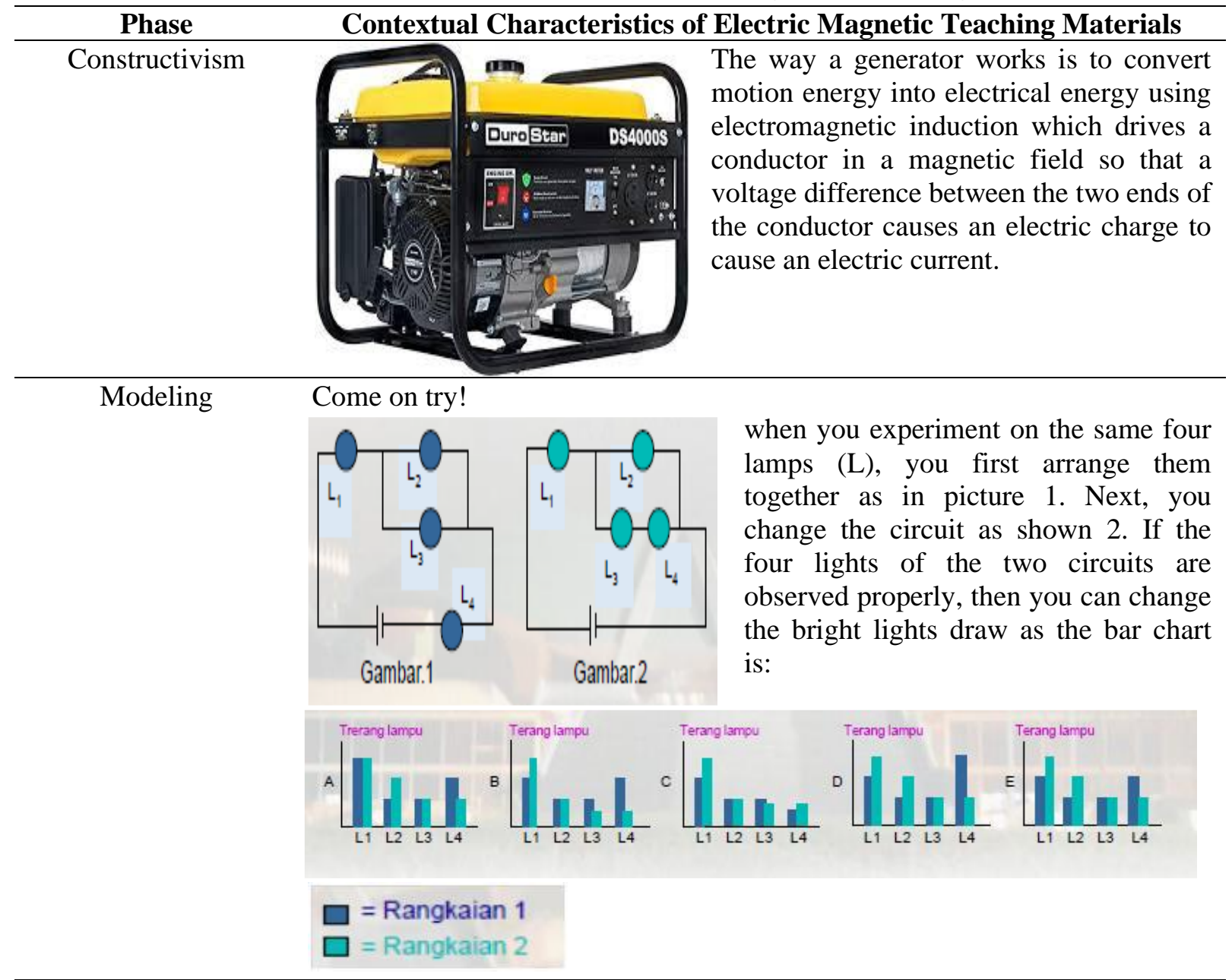

Inquiry

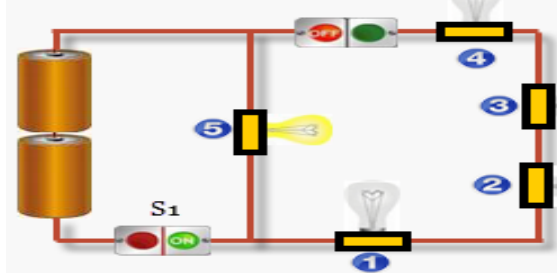

Look at the picture below!

If the switch $\mathrm{S} 1$ is connected, what will happen is ...
a) all lights are on
b) all lights go out
c) lights 5 turns on, lights $1,2,3$, and 4 go out
d) lights 5 go out, lights 1,2,3, and 4 turns on
e) all lights go out. 
Next to make the instrument, an analysis of the assessment tools that in this study that will be measured by researchers includes student learning outcomes and science process skills and is assisted by an observer team from the physics education program 7th semester. In this research, we make and compile a learning strategy that is developing a learning device that is the implementation of the learning plan to develop magnetic electric material in this teaching material.

Furthermore, the revision and validation stages, after the first draft teaching materials have been designed, the researchers then conducted a Group Discussion Forum (FGD) together with physics education lecturer The purpose of this FGD is to look at the content of teaching materials in terms of material, the design used and grammar. In the second draft of teaching material, re-discussing the FGD, the researchers continued to do some things that needed to be improved before conducting the research.

The feasibility of this teaching material theoretically through the stages of expert evaluation to see the validity of teaching materials validated by material experts, design, and grammar so that the teaching materials are good used to students (Nasution, 2012), then in the feasibility stage of teaching materials one trial will be carried out to one, small group and field test. According to Setiawan (2007), the feasibility of contextual physics-based teaching materials on the theoretical feasibility of teaching materials consists of the evaluation of material, design and grammar experts that involves school physics education lecturers as a validator of content and context, as a validator of language aspects, as an expert on additional material. Then for the media experts, the physics study program lecturer was chosen. All of these validators were selected through recommendations from the R\&D Unit of STKIP-PGRI Lubuklinggau to provide assessments and suggestions for teaching materials that researchers developed are shown in Table 6.

Table 6. Recapitulation of Validations of the Three Experts

\begin{tabular}{ccc}
\hline Validation & Percentage & Category \\
\hline Material validation & $86,3 \%$ & Very Good \\
\hline Media validation & $89,3 \%$ & Very Good \\
\hline Language validation & $90,6 \%$ & Very Good \\
\hline Average & $88,73 \%$ & Very Good \\
\hline
\end{tabular}

When the research meeting is conducted in one semester, the schedule of magnet electricity courses is two hours, namely Thursday in the first to second lessons and on Friday the first meeting starts on August 20, 2019. During the field test phase, trials conducted to obtain comprehensive information about the quality of contextual-based teaching material products in the practicality stage, namely to see the practicality of contextual-based physics teaching materials.

The results of the student response questionnaire on the overall field test on contextual based teaching materials were considered to be very good with a percentage of $82.55 \%$. This shows a good response to the use of contextual-based teaching materials. Furthermore, the effectiveness of contextual based teaching materials can be seen from the average value of the results of the Midterm and Midterm Exams. Student scores are said to be sufficient if they get a $\mathrm{C}$ grade. The average midterm score is 78.35 and the average final semester exam score is 
87.45 where 12 students get B grades with good results and 7 students get $\mathrm{C}$ grades (enough) and 13 students received an A (very good). Thus, contextual based teaching materials have been effectively used.

Based on these results it was found that the one-tail hypothesis test in this study with a degree of freedom 0.05 obtained the value of $t$ arithmetic $=6.86$ and the value of $t$ table $=$ 1.706. Because the $t$ value is greater than the table value, it means that contextual based teaching materials are effective for use. Thus, contextual-based teaching materials are valid, practical, and effective. From the findings, it is concluded that good teaching materials will help students in learning activities because teaching materials are considered important in supporting student success such as contextual based teaching materials that implement five contextual steps including observing, asking, trying, reasoning, and communicating.

This is in line with research conducted by Sujanem (2012) and Murtiani (2012) which states that teaching materials are a very important educational component in the learning process. The availability of quality teaching materials will support the success of the learning process.

From the expert response recapitulation, it can be concluded that contextual physicsbased teaching materials on magnetic electric material that based on the final percentage value with a value of $88.73 \%$ with the category of Very Good these teaching materials are said to be valid. The Eligibility of Teaching Materials Empirically, consisting of the implementation of one to one test, small groups and field tests, as well as the implementation of the teaching materials eligibility which will be applied to these teaching materials, shows the student's response to contextually based learning on dynamic electric material with excellent categories so the teaching material is feasible used and applied. Based on the results of the assessment of material, language, and grammar experts, magnetic teaching materials are very feasible to use. The final product as shown in Figure 1.

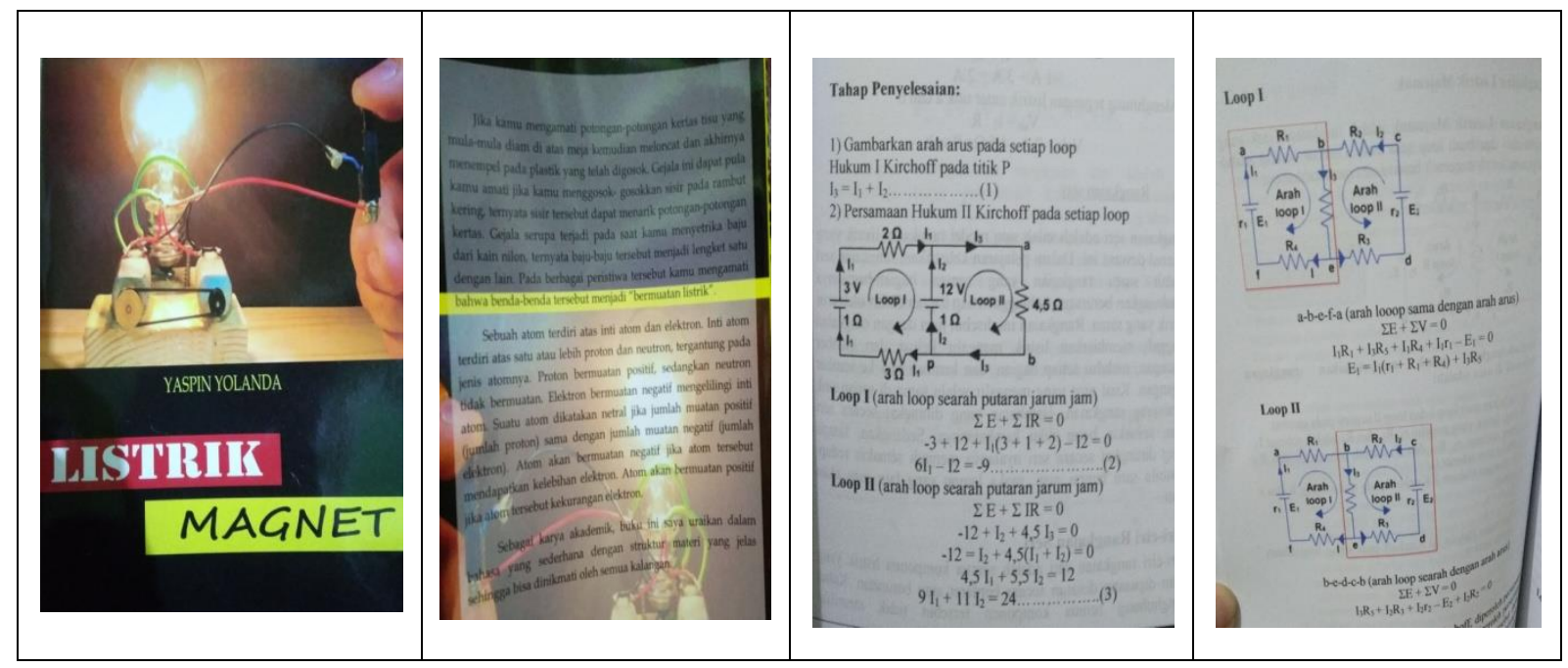

Figure 1. The final revision of teaching materials 


\section{Conclusion}

Teaching Materials are validated by experts namely material, language and graphic design experts. Teaching Materials are also measured practicality levels with one-to-one trials (Revision-1), small group trials (Revision-2) and Final tests (Revision-3). Based on the results of the study show (1) Magnetic electric teaching materials that fit students' needs are contextual based magnetic electric teaching materials and (2) Based on evaluations in accordance with the suggestions and responses from experts. shows the quality of contextualbased physics teaching materials with the overall percentage of these components is very feasible. So that magnetic teaching materials are valid and practical.

\section{References}

Borg, W. R. \& Gall M. D. (2010). Educational Research AnIntruction.fourth edition. New York: Longman

Chaedar. A . 2009. Tujuan Pendidikan Kontekstual. Bandung. Mizan Learning Centre.

Demirci, N. danCirkinoglu, A. (2004). “Ditermining Students' Preconception/Misconceptions in Electricity and Magnetism".Journal of Turkish science education.1, (2), 50- 54.

Draganidis, Fotis, GregorisMentzas. 2006. Competency Based Management: A Review of Systems and Approaches; Information Management \& Computer Security; 14(1); p 5164.

Engelhardt, P. V. dan Beichner, R. J. (2004). "Students' Understanding of Direct Current Resistive Electrical Circuits". American Journal Physics. 72, (1), 98 - 115.

Emzir.2011. Metode Penelitian Kualitatif Analisis Data. Jakarta: raja GrafindoPersada.

Emzir. 2013. Metodologi Penelitian Pendidikan: Kuantitatif dan Kualitatif. Cetakan ke7.Jakarta: Raja Grafindo Persada.

Fayakun, M \&Joko, P., 2015. Efektivitas Pembelajaran Fisika Menggunakan Model Kontekstual (CTL) dengan Metode Predict, Observe, Explain Terhadap Kemampuan Berpikir Tingkat Tinggi. Jurnal Pendidikan Fisika Indonesia. 11(1); 49-58. DOI: 10.15294/jpfi.v11i1.4003.

Gay, L.R. dan Geoffrey E. Mills Peter Airasian. 2009.Educational Research: Competencies for Analysis and Applications. Colimbus Ohio. New Jersey.

Itamar, Gati, \& Itay Asher, 2001.The PIC Model for Career Decision Making: Prescreening, In-Depth Exploration, and Choice. New Jersey: Lawrence Erlbaum Associates, Publishers Mahwah.

Johnson, Elaine B. 2009. Contextual Teaching And Learning.Bandung. Mizan Learning Centre.

Kauffman. 2009. Conceptual Modelling. New York: Prentice Hall.

Law, A.M danKelton, W.D, 1991.Simulating Modelling and Analysis. New York: Mc. Graw Hill. Inc.

Nasir, M., 2017. Analisis Kesulitan Belajar dan Miskonsepsi Mahasiswa Dalam Praktikum Berbasis Proyek. EDU Sains: Jurnal Pendidikan Sains \& Matematika. 5(1); 56-65.

Nugraheni, D., 2017. Analisis Kesulitan Belajar Mahasiswa pada Mata Kuliah Mekanika. Edu Sains: Jurnal Pendidikan Sains \& Matematika. 5(1); 23-32.

Marreli, Anne F., Janis Tondora, and Michael A. Hoge, 2005.Strategies for Developing Competency Models; Administration and Policy in Mental Health, 32(5). 
Matsun1 \& Ramadhani, D., 2018. Perancangan Media Pembelajaran Listrik Magnet Berbasis Android di Program Studi Pendidikan Fisika IKIP PGRI Pontianak. Jurnal Pendidikan Informatika dan Sains. 7(1); 107-117.

Mukayatun (2013). Biology Learning with CTL Approach with Network Tree Technique and Spider Concept Map Judging from the Students' Creativity and Thinking Style. Journal of Inquiry, 2(1); 14-24.

Murtiani. (2012). Application of Lesson Study Based Contextual Teaching And Learning (CTL) Approaches in Improving the Quality of Physics Learning in Padang City Middle School. Journal of Physics Learning Research, 1 (1); 1-21.

Nasution. 2012. Kurikulum Pengajaran. Jakarta: PT Bumi Aksara

Planinic, M. (2006). "Assessment of Difficulties of Same Conceptual areas from Electricity and Magnetism Using The Conceptual Survey of Electricity and magnetism". American Journal of Physics. 74, (12), 1143 - 1148.

Riadi, A., \& Retnawati, H., 2014. Pengembangan Perangkat Pembelajaran untuk Meningkatkan HOTS pada Kompetensi Bangun Ruang Sisi Datar. PYTHAGORAS: Jurnal Pendidikan Matematika. 9(2); 126-135.

Serway, Raymond A. danJhon W. Jewett. 2009. FISIKA untuk Sains dan Teknik. Jakarta: Salemba Teknika.

Setiawan, Denny, dkk.2007. Pengembangan Bahan Ajar. Jakarta: UniversitasTerbuka

Singh, C. (2006). "Student Understending of Symmetry and Gauss's Law of Electricity".American Journal Physics. 74, (10), 923 - 936.

Sugiyono. 2008. Metode Penelitian Pendidikan: Pendekatan Kuantitatif, Kualitatif, dan R \& D. Bandung: Alfabeta.

Sujanem, R., 2012. Pengembangan Modul Fisika Kontekstual Interaktif Berbasis Web Untuk Meningkatkan Pemahaman Konsep dan Hasil Belajar Fisika di Singaraja. Jurnal Nasional Pendidikan Teknik Informatika (JANAPATI). 1(2); 103-117.

Suseno, N., 2010. Kendala Penerapan Inkuiri Dalam Perkuliahan Listrik-Magnet di LPTK. Jurnal Pengajaran MIPA. 15(2); 95-102.

Thiagarajan, S., Semmel, D. S., dan Semmel, M. L. (1974). Instructional Development for Training Teachers of Exceptional Children.Broomington: Indiana University.

Tomlinson, Brian. 2011. Materials Development in Language Teaching Comridge:University Press.

Trianto. 2013. Mendesain Model Pembelajaran Inovatif-Progresif Konsep, Landasan, dan Implementasinya pada Kurikulum Tingkat Satuan Pendidikan (KTSP). Jakarta: Kencana Prenada Media Group

Utomo, L. A., \& Muslimin. 2015. Pengembangan Bahan Ajar Berbasis Multimedia PembelajaranInteraktif Model Borg And Gall Materi Listrik Dinamis Kelas X SMA Negeri 1 Marawola. Jurnal Pendidikan Fisika Tadulako (JPFT). 4(2);10-16.

Yanti, Ana Isqa Riski. 2013. Jurnal Analisis Buku Pelajaran Fisika Sekolah Menengah Atas Kelas X yang Banyak Digunakan di SMA Negeri Se-KabupatenKebumen.3 (2), 4-3.

Yasa, G. A. A. S., 2012. Pengembangan Bahan Ajar Online Mata Kuliah Micro Teaching dengan Model Borg \& Gall pada Program S1 Pendidikan Bahasa Inggris STKIP Agama Hindu Singaraja. Tesis. Program Studi Teknologi Pembelajaran, Program Pascasarjana Universitas

Pendidikan

Ganesha,

Singaraja.

$1-16$. 
https://www.neliti.com/id/publications/207120/pengembangan-bahan-ajar-online-matakuliah-micro-teaching-dengan-model-borg-gall

Yolanda. Y. 2018. Profil Keterampilan Proses Sains Fisika siswa SMA di Kota Lubuklinggau pada pokok bahasan Listrik Dinamis. Thabiea: Journal of Natural Science Teaching. Program Studi Ilmu Pengetahuan Alam IAIN Kudus. 1(2); 70-78. http://dx.doi.org/10.21043/thabiea.v1i2.4067

Yolanda, Y. (2019). Profil Keterampilan Proses Sains (KPS) Mahasiswa Fisika pada Materi Listrik Magnet. JIPFRI (Jurnal Inovasi Pendidikan Fisika Dan Riset Ilmiah), 3(2), 7078. https://doi.org/10.30599/jipfri.v3i2.533 